\title{
Analysis of processing variables in Equiangular Channel Press deformations
}

\author{
Análise das variáveis de processamento em deformações por Prensagem em Canais equiangulares \\ Análisis de variables de procesamiento en deformaciones Presionando em Canales Equiangulares
}

Received: 11/10/2021 | Reviewed: 11/19/2021 | Accept: 11/27/2021| Published: 12/09/2021

\author{
Reinan Tiago Fernandes dos Santos \\ ORCID: https://orcid.org/0000-0001-6469-5647 \\ Universidade Federal de Sergipe, Brazil \\ E-mail: reinantiago@hotmail.com \\ Wilton Walter Batista \\ ORCID: https://orcid.org/0000-0001-6667-8947 \\ Universidade Federal de Sergipe, Brazil \\ E-mail: wiltonwalter@hotmail.com
}

\begin{abstract}
Equiangular Channel Pressing (ECAP) is by far the most promising technique, by the severe plastic deformation (SPD) method, being able to produce large volumes of materials sufficient for practical applications. The ECAP process can be repeated until refining saturation is reached, leading to large amounts of shear strain. The reason behind the exceptional properties obtained in materials processed by ECAP was attributed to the microstructure of the material obtained in this deformation process. This work investigated the ECAP strain variables in the literature in order to analyze the effect of each of these on the microstructure of processed materials. The articles were collected from the following databases: ScienceDirect and the Scientific Electronic Library Online (SciELO) electronic library, as they include national and international literature. Based on the results found, it could be seen that several parameters must be analyzed to deform pure metals and alloys, to refine the microstructure, such as bending angle and channel angle of the strain matrix, number of passes, and pressing temperature. It was possible to verify that changes in these variables configure changes in the microstructure.
\end{abstract}

Keywords: Equiangular Channel Pressing; SPD; Processing variables; Angle of curvature; Channel angle.

\section{Resumo}

A Prensagem em Canais Equiangulares (ECAP) é de longe, a técnica mais promissora, pelo método de deformação plástica severa (SPD) sendo capaz de produzir grandes volumes de materiais suficientes para aplicações práticas. O processo ECAP pode ser repetido até que a saturação de refino seja atingida, levando a grandes quantidades de deformação cisalhante. A razão por trás das propriedades excepcionais obtidas em materiais processados por ECAP foi atribuída à microestrutura do material obtida nesse processo de deformação. Este trabalho investigou na literatura as variáveis de deformação do ECAP afim de analisar o efeito de cada uma destas na microestrutura dos materiais processados. Os artigos foram colhidos das bases de dados: ScienceDirect e biblioteca eletrônica Scientific Electronic Library Online (SciELO), por contemplarem a literatura nacional e internacional. Baseando-se nos resultados encontrados, pôde-se perceber que diversos parâmetros devem ser analisados para deformar metais puros e ligas, para refinar a microestrutura, como ângulo de curvatura e ângulo de canal da matriz de deformação, número de passagens, e temperatura de prensagem. Foi possível verificar que alterações nessas variáveis configuram alterações na microestrutura.

Palavras-chave: Prensagem em Canais Equiangulares; SPD; Variáveis de processamento; Ângulo de curvatura; Ângulo do canal.

\section{Resumen}

El prensado en canal equiangular (ECAP) es, con mucho, la técnica más prometedora, mediante el método de deformación plástica severa (SPD), pudiendo producir grandes volúmenes de materiales suficientes para aplicaciones prácticas. El proceso ECAP se puede repetir hasta que se alcanza la saturación del refinado, lo que genera grandes cantidades de deformación por cizallamiento. La razón de las excepcionales propiedades obtenidas en los materiales procesados por ECAP se atribuyó a la microestructura del material obtenido en este proceso de deformación. Este trabajo investigó las variables de deformación ECAP en la literatura con el fin de analizar el efecto de cada una de ellas en la microestructura de los materiales procesados. Los artículos fueron recolectados de las siguientes bases de datos: ScienceDirect y Scientific Electronic Library Online (SciELO), ya que incluyen literatura nacional e internacional. Con base en los resultados encontrados, se pudo ver que se deben analizar varios parámetros para deformar metales puros y aleaciones, para refinar la microestructura, como el ángulo de flexión y el ángulo de canal 
de la matriz de deformación, el número de pasadas y la temperatura de prensado. Se pudo comprobar que cambios en estas variables configuran cambios en la microestructura.

Palabras clave: Prensado de canal equiangular; SPD; Procesamiento de variables; Ángulo de curvatura; Ángulo de canal.

\section{Introduction}

Metal processing through severe plastic deformation (SPD) has attracted a lot of attention due to the potential to achieve grain refinement at the submicron level, and in some conditions, at the nanometer scale (Valiev, Lowe \& Mukherjee, 2000). Investigations with SPD have shown that the microstructure of materials not only improves mechanical properties (Stolyarov et al., 2001), but also alters biocompatibility (Faghihi et al., 2007) and corrosion properties (Hoseini et al., 2009).

There are two main advantages of SPD processing. First, it has the potential to produce large samples without introducing any porosity or contaminants. Second, conventional SPD processing can be applied relatively easily to a wide range of metal alloys without the need to make any significant changes to processing variables (Xu et al., 2005).

Among the various SPD techniques, the Equal Channel Angular Pressing (ECAP) method is by far the most promising technique, being able to produce large volumes of materials, sufficient for practical applications. ECAP metal processing has become important for the production of materials with exceptionally small grain sizes (Valiev \& Langdon, 2006). This SPD technique imposes much higher deformations on the crystal lattice, capable of producing an ultra-fine grain (UFG) microstructure not obtained with conventional cold working methods such as cold rolling, twisting and compression (Valiev, 2004).

Various processing parameters are able to affect the level of refinement during ECAP deformation. Many studies have been carried out with the aim of showing the refinement of the microstructure as a function of processing parameters: number of passes in processing (Zhao et al., 2010), types of processing routes (Suwas et al., 2007; Iwahashi, Horita, \& Nemoto, 1998), channel angle and bending angle of the processing matrix (Valiev \& Langdon, 2006) and the processing temperature (Yamashita et al., 2000). However, there is a lack in the literature of an investigation that analyzes all these discoveries, in a single approach, about the microstructure aspect of materials processed by ECAP. In this context, this report aims to analyze in the literature the processing variables that interfere with ECAP deformation.

\section{Methodology}

The present study used the literature review as a method, which aimed to gather and summarize the scientific knowledge already produced on the topic investigated, that is, it allows searching, evaluating and synthesizing the available evidence to contribute to the development of knowledge in the subject. Literature review is important in: supporting the identification of a theme, question or research hypothesis; identify the literature to which the research will contribute and contextualize the research within this field; build an understanding of theoretical concepts and terminology; facilitate the construction of a bibliography or list of consulted sources (Rowley \& Slack, 2004).

This investigation was conducted with the following guiding questions: How has the national and international literature considered the processing variables by ECAP? And knowing from scientific publications on Materials how these variables have inferred in the microstructure of materials deformed by this technique?

The search was carried out in the following databases: ScienceDirect and electronic library Scientific Electronic Library Online (SciELO). We chose these databases and library because we understand that they reach the national and international literature, as well as technical-scientific references and reputable periodicals in the Materials area. The following descriptors were used: ECAP; Processing variables, SPD. 


\section{Results and Discussion}

\subsection{Processing by ECAP}

Among the SPD techniques presented, ECAP is the most promising method. Although this method does not allow the formation of grains smaller than $100 \mathrm{~nm}$, it is attractive because it is relatively cheap and because it is able to process a large amount of material without changing its cross section (Aida et al., 2001; Zhu \& Lowe, 2000). ECAP also allows the deformed samples to have sufficient dimensions to allow the performance of tensile and compression tests (Valiev, 2004).

ECAP was first invented and described in 1972 for application to different materials to solve problems in industry. In the early 1990s with growing interest in ultra-fine materials, ECAP became the object of considerable efforts and research on this type of deformation increased. Several works have been published with alloys analyzing the evolution of microstructure and its relationships with properties, focused on the refinement of highly deformed metal grains, which is one of the applications of ECAP (Segal, 1974).

Theoretical and experimental modeling of ECAP mechanics was carried out through computational simulation, using the finite element technique and enabled ECAP compression matrix designs to obtain a microstructure characteristic of uniform ultrafine grains. Deformation intensity and contact pressure distribution images were obtained during different friction conditions, between the sample and the ECAP channel. Thus, modifications were introduced in the matrices developed so far, based on the results obtained from the experimental modeling (Valiev, 2004; Stolyarov et al., 2001).

The ECAP technique aims to introduce a severe plastic deformation to a material without changing the cross-section of the sample, in this way it is possible to refine the material by the number of passes through the matrix, increasing the level of deformation (Popov et al., 2019; Segal et al., 1997; Xu et al., 2005).

ECAP is a shear deformation method, performed in a matrix with two channels connected together that intersect at an angle $\theta$ (often $\theta=90^{\circ}$ or $120^{\circ}$ ). Depending on the processed material and the desired properties, this angle can vary between $90^{\circ}$ to $157.5^{\circ}$. For deformation, the sample is placed in the first channel and pressed through a punch. Figure 1 shows how this deformation process takes place (Valiev \& Langdon, 2006; Sivakumar \& Ortiz, 2004).

Figure 1. Schematic drawing of an ECAP process.

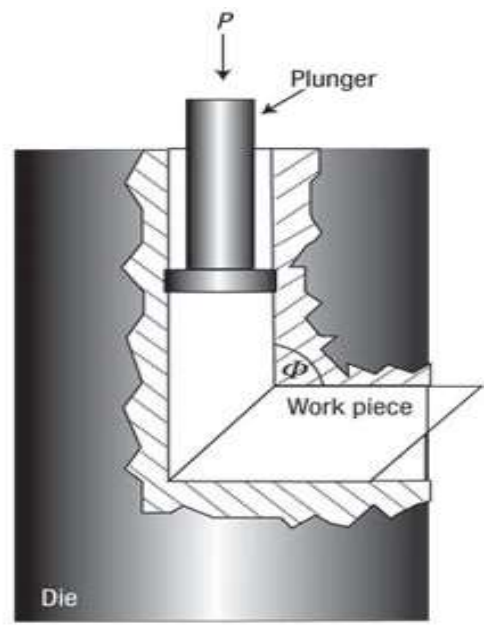

Source: Valiev (2004). 


\subsection{Experimental factors influencing metallic materials processed by ECAP}

\section{a) Number of passes}

One of the main factors influencing the properties of materials submitted to ECAP is the number of passes or number of times the sample is processed. The increase in the number of passes allows raising the level of deformation imposed on the material and promoting greater homogeneity of deformation throughout the sample (Sordi et al., 2012). With the increase in the number of passes applied, the intersection of deformation bands in the structure is intensified, providing a greater degree of refinement, generally leading to the formation of grains with nanometric dimensions (Langdon, 2013).

A mechanism for grain refinement when processing through ECAP is represented in the schematic illustrations in Figure 2, where the microstructure is shown in the $\mathrm{Y}$, or longitudinal plane, the three lines correspond to 1, 2 and 4 ECAP passes, the three columns correspond to processing routes $\mathrm{A}, \mathrm{BC}$, and $\mathrm{C}$, and the angle of all slide systems $\eta$ is indicated below each illustration. The colors follow the sequence used with red, lavender, green and blue representing the slip lines introduced in the first, second, third and fourth pass, respectively, and the width of the subgrain bands is equal to $\mathrm{d}$ for each pass through the matrix. In processing using the $\mathrm{BC}$ route, there is greater angular variation $\eta$ a very high density of unconformities in the first pass, as the number of passes increases, the thickness of cell walls decreases by recovery, leading to an excess of unconformities of only one signal at each contour and to the formation of a matrix of ultrafine grains separated by high-angle and out-of-balance contours. The development of an equiaxed microstructure is less advanced when using routes $\mathrm{A}$ and $\mathrm{C}$ after four passes, due to the low value of the angular range, $\eta$, for these two routes (Langdon, 2007).

Figure 2. Model for grain refinement via ECAP where sub grains are formed with a width of d, the results are illustrated in the Y or longitudinal plane, for 1, 2 and 4 passes.

\section{$\underline{\text { plane }}$}

$1 \mathrm{p}$

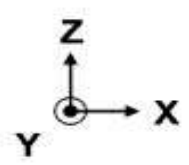

$\underline{\mathbf{A}}$

$\underline{2 p}$

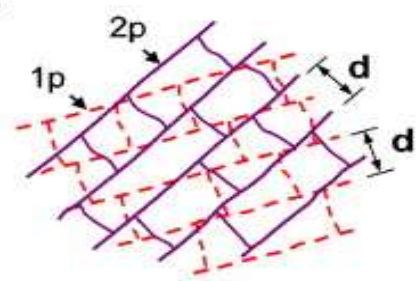

$\underline{n}=27^{\circ}$

$\underline{4 p}$

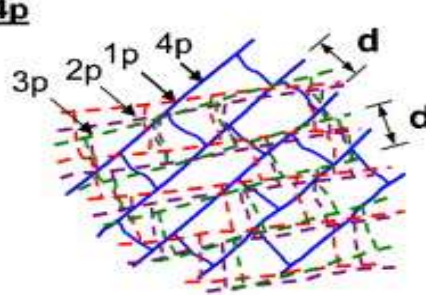

$\underline{\eta}=37^{\circ}$

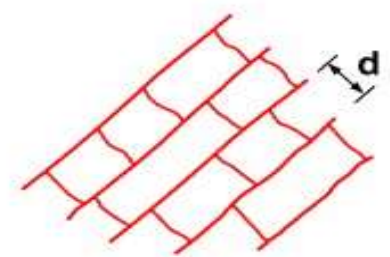

$\underline{\mathbf{B}_{c}}$<smiles>[SiH3]</smiles>

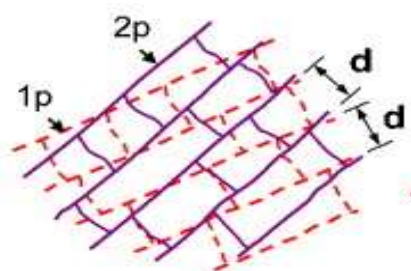

$\eta=18^{\circ}$

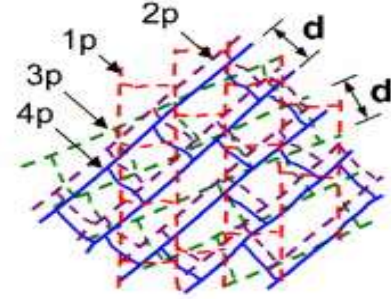

$n=63^{\circ}$

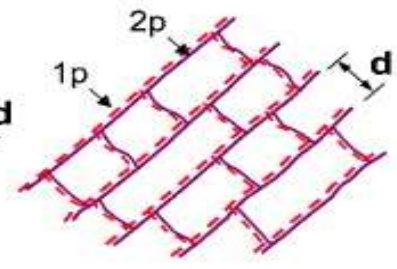

$\underline{\eta}=0^{\circ}$

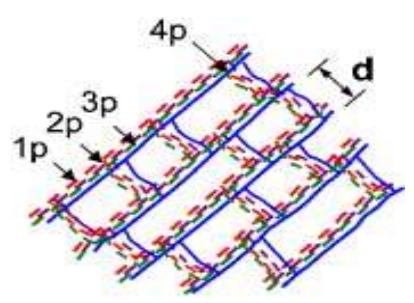

$\underline{\eta}=0^{\circ}$

Source: Langdon (2007).

Abd el aal and Sadawy, (2015) processed Al1080 samples by ECAP using 2, 4 and 10 passes. Increasing the number of ECAP passes by up to 10 passes is effective in allowing for a further decrease in grain size (up to $0.3 \mu \mathrm{m}$ ) and an increase in 
the ratio between high angle contours (up to 78\%). The ECAP process has been used successfully in the refinement of the microstructure.

Zhao et al., (2010) identified a problem in the processing of commercially pure Titanium (Ti CP) at room temperature through the angle $\theta=120^{\circ}$, from the study of passages through ECAP and found that above 8 passes the samples of Ti CP fractured, demonstrating its maximum limit of deformation. And up to the fracture limit the samples showed a reduction in grain size from $23 \mu \mathrm{m}$ to $200 \mathrm{~nm}$ and the tensile strength increased from $530 \mathrm{MPa}$ to $790 \mathrm{MPa}$.

\section{b) Processing routes}

After the first pass through the ECAP matrix channel, the cross-sectional area of the deformed sample remains unchanged, it is possible that the same sample is repeatedly placed in the matrix channel, capable of promoting high deformations (Furukawa et al., 1998). The importance of rotation between multiple passes was identified by (Segal, 1995), who identified that different routes used between passes would result in different and specific microstructures of the route used.

The multiple passes via ECAP make it possible to rotate the samples around their longitudinal axis between consecutive passes, creating different ECAP routes, which significantly influence the refinement of the grains and their shape, so it is of interest to find the most efficient route in grain refinement (Stolyarov et al., 2001; Zhu \& Lowe, 2000).

Currently, the literature defines four processing routes between passes and their influence on the materials microstructure. Figure 3 illustrates these four routes for more than one pass through the ECAP matrix (Adedokun, 2011; Iwahashi et al., 1998; Roodposhti et al., 2015).

- Route A: The position of the deformed specimen is maintained, there is no rotation around the axis between each pass;

- Route BA: The specimen is rotated $90^{\circ}$ clockwise and counterclockwise, alternately, between each pass;

- Route BC: the sample is rotated by $90^{\circ}$ between each extrusion cycle, always in the same direction;

- Route C: the sample is rotated $180^{\circ}$ in the same direction.

Figure 3. Four different ECAP matrix processing routes. How the sample leaves the matrix and the specific route to the next pass in the channel.

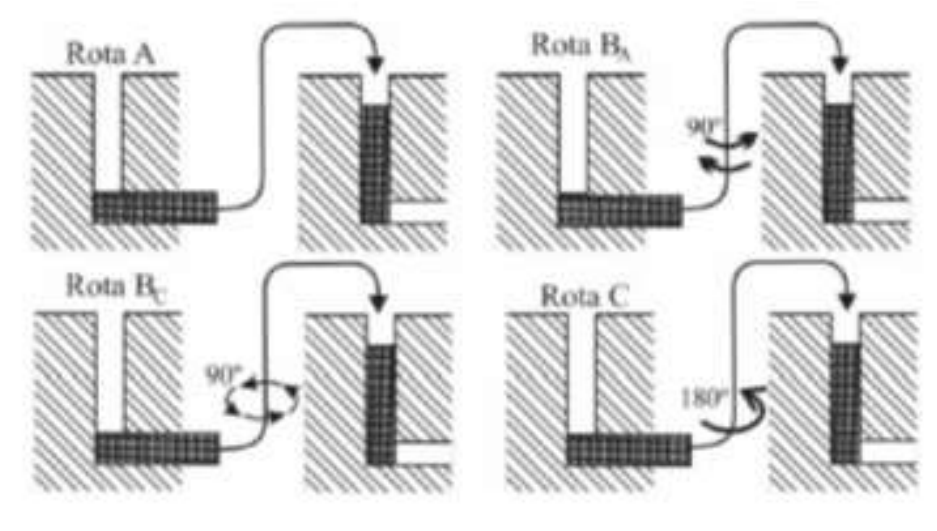

Source: Adedokun (2011).

Suwas et al., (2007) processed pure $\mathrm{Mg}$ via ECAP at high temperature $\left(250^{\circ} \mathrm{C}\right)$ via route $\mathrm{A}, \mathrm{BC}$ and $\mathrm{C}$ in up to four passes, and observed that the evolution of the strain texture increased with the number of ECAP passes. Each route gave rise to 
a characteristic texture. The routes that most refined the grains were $\mathrm{C}$ and $\mathrm{BC}$, which presented an average grain size of 6$8 \mu \mathrm{m}$ after four passes.

The microstructure difference attributed to each of the passes is justified by the difference in the number and directions of the turns between each one of the passes through the deformation matrix. For different routes, different planes and shear direction are activated (Zhu \& Lowe, 2000).

In the works of Iwahashi et al. (1998) it was possible to verify that the microstructure evolves more quickly to a matrix with high angle contours when the deformation is conducted using the $\mathrm{BC}$ route, when comparing the imposed deformations with the A routes, BA and C, this formation is justified by the duality of the shear planes in the $\mathrm{BC}$ route, where the subgrains are created in two different sets of planes with the increase in the number of passes. Between routes $\mathrm{A}$ and $\mathrm{C}$, the evolution of contours from low to high angle was more intense in $\mathrm{C}$, since the deformation occurs in a single shear plane.

\section{c) Curvature angle $(\Psi)$ and channel angle $(\theta)$}

In addition to the processing route, another factor that significantly affects the material's microstructure is the angle of intersection of the channels (Zhu \& Lowe, 2000). In the ECAP process, the homogeneous and uniform shear deformation $(\gamma)$ depends on the channel angle $(\theta)$ and the curvature angle $(\Psi)$.

The relation of the true strain $(\varepsilon)$ as a function of the number of passes $(N)$ as proposed by Segal et al., (1997) is obtained by the following equation:

$$
\varepsilon=\frac{2 \operatorname{Noot}\left(\frac{\pi}{2}\right)}{\sqrt{a}} \quad \text { (Eq. 1) }
$$

The deformation condition where $\Psi \neq 0$, proposed by Iwahashi et al., (1996) the true deformation $(\varepsilon)$ can be obtained by equation (2):

$$
\varepsilon=\frac{\mathbb{W}}{\sqrt{a}}\left[2 \cot \left(\frac{\Theta}{2}+\frac{\Psi}{2}\right)+\Psi_{\operatorname{cosec}}\left(\frac{\Theta}{2}+\frac{\Psi}{2}\right)\right] \quad \text { (Eq. 2) }
$$

This equation provides a simple and straightforward procedure to estimate the deformation for any ECAP processing condition, as long as $\theta$ and $\Psi$ are known (Valiev \& Langdon, 2006).

The study of the severity due to the angle of the channel $\theta$ was associated with the finite element method applied to the condition of plane deformation, in the absence of friction, and it was observed that the magnitude of the effective plastic deformations was affected by $\theta$, which exerts very important influence on the distribution of strain in samples submitted to ECAP (Queiroz et al., 2014; Skrotzki, 2019).

Dumoulin et al., (2005) observed that the hardening exponent and the friction conditions, in this case the $\theta$, were shown to be more relevant on the homogeneity of effective plastic deformations. On the other hand, the authors identified that with the increase of $\theta$, there was a reduction in the mean value of effective deformation, although the maximum deformation homogeneity value was reached for intermediate angles, as is the case for $110^{\circ}$ angles, as shown in Figure 4. 
Figure 4. Effects of the $\theta$ angle on the homogeneity of deformations and sample curvature.

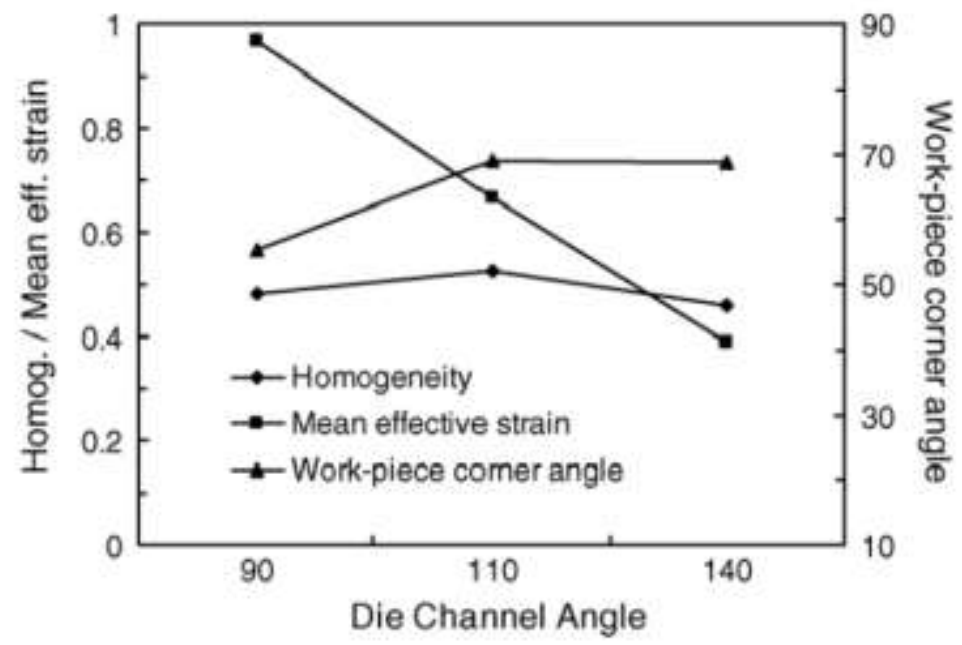

Source: Dumoulin et al. (2005).

Experiments were conducted by Nakashima et al., (1998) to investigate the influence of the channel angle, $\theta$, and the arc of curvature, $\Psi$, on the development of an ultrafine grain structure. The tests were performed using dies with channel angles of $90^{\circ}, 112.5^{\circ}, 135^{\circ}$ and $157.5^{\circ}$ and arc of curvature $\Psi$ ranging between $10^{\circ}$ and $30^{\circ}$. The samples were deformed by 4 , 6,9 and 19 passes in dies with angles of $90^{\circ}, 112.5^{\circ}, 135^{\circ}$ and $157.5^{\circ}$. This allowed all samples to have the same total equivalent strain level ( 4).

The authors used the finite element method applied to the plane strain condition, in the absence of friction, and observed that the magnitude of the effective plastic strain was affected by $\theta$ and $\Psi$, with the higher $\Psi$, the smaller the amount of strain attributed to the material by extrusion pass (Queiroz et al., 2014). The angle $\Psi$ has little influence on the deformation imposed on the sample, but it was observed that it influences the homogeneity of deformation in the sample. The greater the angle $\Psi$, the greater the homogeneity (Valiev \& Langdon, 2006; Aida et al., 2001). For $\theta$ equal to or greater than $90^{\circ}$, any value of $\Psi$ produces a variation in deformation of less than 5\% (Aida et al., 2001).

\section{d) Temperatura de prensagem}

Temperature is one of the factors that influence the microstructure in materials deformed by ECAP (Figueiredo et al., 2016). For a better refined structure the lowest possible temperature must be conducted during the deformation process, with an increase in the deformation temperature the grain size increases as well as the fraction of low angle contours. The latter is justified by the high rate of recovery, dependent on the material, which facilitates the annihilation of disagreements within the grains and, consequently, a decrease in the number of disagreements absorbed in the subgrain walls (Valiev \& Langdon, 2006; Yamashita et al., 2000).

In the deformation process via ECAP, the temperature increase can result in an increase in the size of the final subgrains produced. Mazurina et al., (2008) classified microstructural changes into three phases: (1) formation of deformation bands; (2) development of large bands and grain fragmentation; (3) rapid emergence of new grains. Of the three phases, (3) is the only one that is influenced by high temperatures. Since the increase in the deformation temperature leads to the fraction of new grains and an increase in their size in phase 3.

In samples of pure aluminum and its alloys (alloy $\mathrm{Al}-3 \mathrm{Mg}$ and $\mathrm{Al}-3 \mathrm{Mg}-0.2 \mathrm{Sc}$ ) processed in ECAP at a temperature of $573 \mathrm{~K}$, the results of these experiments showed two important trends. First, there was an increase in grain size with increasing 
temperature, as illustrated in Figure 5, another observation was the increase in the number of low-angle contours with increasing temperature (Yamashita et al., 2000).

Figure 5. Grain size and processing temperature for pure $\mathrm{Al}, \mathrm{Al}-3 \% \mathrm{Mg}$ and $\mathrm{Al}-3 \% \mathrm{Mg}-0.2 \% \mathrm{Sc}$ alloys deformed by ECAP.

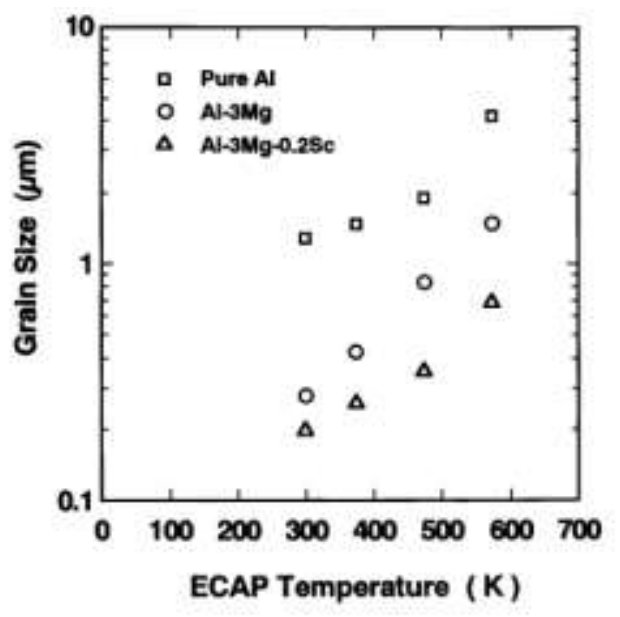

Source:Yamashita et al. (2000).

The average grain size increases with increasing processing temperature, while the fraction of high angle contours shows the opposite trend due to faster recovery and decrease associated with displacements absorbed in the subgrain walls. Although it is easier to process samples at elevated temperatures, a microstructure with the finest grains and the largest fraction of high-angle contours is obtained when ECAP is performed at the lowest possible temperature (Sabirov et al., 2013).

\section{Final Considerations}

Currently, ECAP is the most successful of potential SPD processing techniques, this technique is an effective tool for grain refinement and microstructural evolution, it is the most researched method, as it is easy to handle and high grain refining. In this study it was possible to analyze the obtainment of ultra-fine grain materials through processing, the grain size varies according to the material characteristics and the experimental factors of the process.

The technical variables of the process involve: the number of passes in the deformation matrix; number of tickets; processing routes; curvature angle $(\Psi)$ and channel angle $(\theta)$; pressing temperature. Therefore, all these fundamental and experimental variables play an essential tool in optimizing the pressing technique and operation. Using the definitions introduced, there is now a good understanding of the basic variables of ECAP processing, and the role of these variables in the particle size of these deformed materials.

By verifying the aspects presented in this work, it is concluded that the analysis involving alloys deformed by pressing in equiangular channels is an area that provides ample possibilities for study, whose objective should be to enable pure alloys and metals with better mechanical properties, corrosion resistance and excellent fatigue resistance and inert properties in biological systems. The authors suggest as a future work to analyze the state of the art of the homogeneity of hardness and microstructure of materials by ECAP according to the processing variables presented.

\section{Acknowledgments}

This work was supported by Foundation to Support Research and Technological Innovation of the State of Sergipe [FAPITEC/SE - nº 07/2018]. 


\section{References}

Abd el aal, M. I., \& Sadawy, M. M. (2015). Influence of ECAP as grain refinement technique on microstructure evolution, mechanical properties and corrosion behavior of pure aluminum. Transactions of Nonferrous Metals Society of China, 25(12), 3865-3876.

Adedokun, S. T. (2011). A review on equal channel angular extrusion as a deformation and grain refinement process. Journal of Emerging Trends in Engineering and Applied Sciences, 2(2), 360-363.

Aida, T., Matsuki, K., Horita, Z., \& Langdon, T. G. (2001). Estimating the equivalent strain in equal-channel angular pressing. Scripta Materialia, 44(4), 575579 .

Dumoulin, S., Roven, H. J., Werenskiold, J. C., \& Valberg, H. S. (2005). Finite element modeling of equal channel angular pressing: Effect of material properties, friction and die geometry. Materials Science and Engineering: A, 410-411, 248-251.

Faghihi, S., Azari, F., Zhilyaev, A. P., Szpunar, J. A., Vali, H., \& Tabrizian, M. (2007). Cellular and molecular interactions between MC3T3-E1 preosteoblasts and nanostructured titanium produced by high-pressure torsion. Biomaterials, 28(27), 3887-3895.

Figueiredo, R. B., Poggiali, F. S. J., Silva, C. L. P., Cetlin, P. R., \& Langdon, T. G. (2016). The influence of grain size and strain rate on the mechanical behavior of pure magnesium. Journal of Materials Science, 51(6), 3013-3024.

Furukawa, M., Iwahashi, Y., Horita, Z., Nemoto, M., \& G. Langdon, T. (1998). The Shearing Characteristics Associated with Equal-Channel Angular Pressing 257(2), 328-332.

Iwahashi, Y., Horita, Z., Nemoto, M., \& Langdon, T. G. (1998). The process of grain refinement in equal-channel angular pressing. Acta Materialia, 46(9), 3317-3331.

Iwahashi, Y., Wang, J., Horita, Z., Nemoto, M., \& Langdon, T. G. (1996). Principle of equal-channel angular pressing for the processing of ultra-fine grained materials. Scripta Materialia, 35(2), 143-146.

Langdon, T. G. (2007). The principles of grain refinement in equal-channel angular pressing. Materials Science and Engineering: A, 462(1), 3-11.

Langdon, T. G. (2013). Twenty-five years of ultrafine-grained materials: Achieving exceptional properties through grain refinement. Acta Materialia, 61(19), $7035-7059$

Mazurina, I., Sakai, T., Miura, H., Sitdikov, O., \& Kaibyshev, R. (2008). Effect of deformation temperature on microstructure evolution in aluminum alloy 2219 during hot ECAP. Materials Science and Engineering: A, 486(1), 662-671.

Nakashima, K., Horita, Z., Nemoto, M., \& Langdon, T. G. (1998). Influence of channel angle on the development of ultrafine grains in equal-channel angular pressing. Acta Materialia, 46(5), 1589-1599.

Popov, V. V. \& Popova, E. N. (2019). Behavior of Nb and Cu-Nb Composites under Severe Plastic Deformation and Annealing. Materials Transactions, 60 (7), 1209-1220.

Queiroz, A. V. de, Fernandes, M. T., Silva, L. M. da, \& Neil De, M. (2014). Análise Teórica e Numérica do Processamento Não-Isotérmico de Materiais Via A Técnica de Prensagem em Canais Equiangulares. Cadernos UniFOA. 9 (26), 5-15.

Roodposhti, P. S., Farahbakhsh, N., Sarkar, A., \& Murty, K. L. (2015). Microstructural approach to equal channel angular processing of commercially pure titanium-A review. Transactions of Nonferrous Metals Society of China, 25(5), 1353-1366.

Rowley, J., \& Slack, F. (2004). Conducting a literature review. Management Research News, 27 (6), 31-39.

RZ Valiev ,TC Lowe \&AK Mukherjee. (2000). Understanding the unique properties of SPD-induced microstructures. JOM, 52, 37-40.

Sabirov, I., Murashkin, M. Yu., \& Valiev, R. Z. (2013). Nanostructured aluminium alloys produced by severe plastic deformation: New horizons in development. Materials Science and Engineering: A, 560, 1-24.

Segal, V. M. (1974). Methods of stress-strain analysis in metal-forming. Physical Technical Institute Academy of Sciences of Buelorussia, Minsk, Russia.

Segal, V. M. (1995). Materials processing by simple shear. Materials Science and Engineering: A, 197(2), $157-164$.

Segal, V. M., Hartwig, K. T., \& Goforth, R. E. (1997). In situ composites processed by simple shear. Materials Science and Engineering: A, 224(1), 107-115.

Sivakumar, S. M., \& Ortiz, M. (2004). Microstructure evolution in the equal channel angular extrusion process. Computer Methods in Applied Mechanics and Engineering, 193(48), 5177-5194.

Skrotzki, Werner. (2019). Deformation Heterogeneities in Equal Channel Angular Pressing. Materials transactions, 60 (7), $1331-1343$.

Sordi, V. L., Ferrante, M., Kawasaki, M., \& Langdon, T. G. (2012). Microstructure and tensile strength of grade 2 titanium processed by equal-channel angular pressing and by rolling. Journal of Materials Science, 47(22), 7870-7876.

Stolyarov, V. V., Zhu, Y. T., Alexandrov, I. V., Lowe, T. C., \& Valiev, R. Z. (2001). Influence of ECAP routes on the microstructure and properties of pure Ti. Materials Science and Engineering: A, 299(1), 59-67.

Suwas, S., Gottstein, G., \& Kumar, R. (2007). Evolution of crystallographic texture during equal channel angular extrusion (ECAE) and its effects on secondary processing of magnesium. Materials Science and Engineering: A, 471(1), 1-14. 
Research, Society and Development, v. 10, n. 16, e140101623101, 2021

(CC BY 4.0) | ISSN 2525-3409 | DOI: http://dx.doi.org/10.33448/rsd-v10i16.23101

Valiev, R. (2004). Nanostructuring of metals by severe plastic deformation for advanced properties. Nature Materials, 3(8), 511-516.

Valiev, R. Z., \& Langdon, T. G. (2006). Principles of equal-channel angular pressing as a processing tool for grain refinement. Progress in Materials Science, $51(7), 881-981$

Xu, C., Furukawa, M., Horita, Z., \& Langdon, T. G. (2005). The evolution of homogeneity and grain refinement during equal-channel angular pressing: A model for grain refinement in ECAP. Materials Science and Engineering: A, 398(1), 66-76.

Yamashita, A., Yamaguchi, D., Horita, Z., \& Langdon, T. G. (2000). Influence of pressing temperature on microstructural development in equal-channel angular pressing. Materials Science and Engineering: A, 287(1), 100-106.

Zhao, X., Yang, X., Liu, X., Wang, X., \& Langdon, T. G. (2010). The processing of pure titanium through multiple passes of ECAP at room temperature. Materials Science and Engineering: A, 527(23), 6335-6339.

Zhu, Y. T., \& Lowe, T. C. (2000). Observations and issues on mechanisms of grain refinement during ECAP process. Materials Science and Engineering: A, 291(1), 46-53. 